\title{
PENGARUH CITRA MEREK, KUALITAS PRODUK DAN PROMOSI TERHADAP KEPUASAN KONSUMEN PRODUK ROTIBOY DI KOTA BANDA ACEH
}

\author{
(The Influence of Brand Image, Product Quality And Promotion of Rotiboy's Consumer \\ Satisfaction In The City of Banda Aceh)
}

\author{
Istiqarah Isa Putri ${ }^{1}$, Sofyan $^{1}$, Rahmaddiansyah ${ }^{1 *}$ \\ ${ }^{1}$ Program Studi Agribisnis, Fakultas Pertanian, Universitas Syiah Kuala
}

\begin{abstract}
Abstrak - Dewasa ini, dunia usaha mengalami perkembangan yang sangat pesat, khususnya untuk perusahaan sejenis roti. Mereka di tuntut untuk memiliki suatu keunikan tersendiri yang dapat memikat konsumen. Perusahaan harus mampu membuat perencanaan pemasaran yang baik demi mendapat pencitraan yang positif di benak konsumen. Yaitu dengan cara meningkatkan pencitraan terhadap merek, kualitas produk dan promosi sehingga kepuasan konsumen menjadi tujuan utama perusahaan serta senantiasa memberikan ciri pembeda dengan produk pesaing. Penelitian ini bertujuan untuk melihat bagaimanakah pengaruh citra merek, kualitas produk, dan promosi terhadap kepuasan konsumen produk rotiboy di Kota Banda Aceh. Adapun metode analisis yang digunakan adalah Regresi Linier Berganda. Hasil Regresi Linier Berganda menunjukkan bahwa citra merek, kualitas produk dan promosi secara serempak berpengaruh positif atau signifikan terhadap kepuasan konsumen produk rotiboy di Kota Banda Aceh. Sedangkan, secara parsial citra merek dan kualitas produk berpengaruh positif atau signifikan terhadap kepuasan konsumen produk rotiboy di Kota Banda Aceh. Sedangkan promosi tidak berpengaruh positif atau signifikan terhadap kepuasan konsumen produk rotiboy di Kota Banda Aceh.
\end{abstract}

Kata Kunci: Citra Merek, Kualitas Produk, Promosi, Kepuasan Konsumen

\begin{abstract}
Nowadays, business sectors are rapidly expanding, especially bread companies. For those companies, uniqueness is a need in attracting the customers. They should have a good marketing plan in order to create a positive image of the companies. A good marketing plan includes building a strong brand image, improving product quality, and promoting. Customer satisfaction is the main goal of most of the companies. Therefore, they keep showing their unique characteristics that are different with the others'. The objective of this research was to identify the effect of brand image, product quality, and promotion on the satisfaction of Rotiboy's costumer in Banda Aceh. Multiple liniar regression was used in the process of data analisys. The results showed that brand image, product quality, and promotion simultaneously affected the satisfaction of Rotiboy's costumer in Banda Aceh. The Correlation was positive and significant. In addition, brand image and product quality partially effected the satisfaction of Rotiboy's costumer in Banda Aceh while promotion did not. The correlation was also positive and signifcant.
\end{abstract}

Keyword : Brand Image, Product Quality, Promotion, Customer Satisfaction

*Corresponding author: rahmaddiansyah@unsyiah.ac.id

JIM Pertanian Unsyiah - AGB, Vol. 2, No. 2, Mei 2017: 225-237 


\section{PENDAHULUAN}

Dewasa ini, dunia usaha mengalami perkembangan yang sangat pesat, khususnya untuk perusahaan sejenis roti. Roti dianggap sebagai salah satu makanan pengganti nasi yang banyak disukai atau diminati oleh sebagian besar masyarakat dalam segala usia. Kehadiran industri-industri roti seperti yang terjadi di Kota Banda Aceh memicu terjadinya persaingan antar pengusaha roti. Mereka di tuntut untuk memiliki suatu keunikan tersendiri yang dapat memikat konsumen dalam rangka mempertahankan atau merebut pangsa pasar yang ada. Dalam proses persaingan yang semakin ketat, perusahaan harus mampu membuat perencanaan pemasaran yang baik demi mendapat pencitraan yang positif di benak konsumen. Pihak manajemen di masing-masing perusahaan juga dituntut agar dapat meningkatkan dan mempertahankan pelanggan yang ada.

Citra merek (Brand Image) merupakan keseluruhan persepsi terhadap suatu merek yang dibentuk dengan memproses informasi dari berbagai sumber setiap waktu. Brand Image dibangun berdasarkan kesan, pemikiran ataupun pengalaman yang dialami seseorang terhadap suatu merek yang pada akhirnya akan membentuk sikap terhadap merek yang bersangkutan (Setiadi, 2003). Dengan adanya merek, masyarakat mendapat jaminan tentang suatu mutu produk yaitu dengan memperoleh informasi yang berkaitan dengan merek tersebut. Dikenalnya merek oleh masyarakat membuat pihak perusahaan meningkatkan inovasi produk untuk menghadapi persaingan.

Pertumbuhan industri roti kini semakin marak khususnya di kota Banda Aceh, maka tidak heran jika terjadi persaingan yang sangat ketat. Dengan adanya persaingan ini, maka suatu perusahaan diharuskan untuk dapat memenuhi persyaratan agar dapat bertahan dalam arus persaingan yang sangat ketat. Seperti menciptakan daya tarik pelanggan dan mempertahankan pelanggan. Perilaku seseorang dalam memilih makanan sangatlah dipengaruhi oleh latar belakang hidup seseorang, seperti gaya hidup (pola yang digunakan untuk menghabiskan waktu serta uang) dan sumber daya konsumen. Dalam melakukan pembelian suatu produk, biasanya konsumen akan menilai suatu produk sebelum akhirnya memutuskan untuk membeli produk tersebut, seperti bagaimana kualitas dari produk tersebut, merek dan lain sebagainya.

Rotiboy adalah produk roti asal Malaysia yang didirikan pada bulan April 1998 di Bukit Mertajam, Penang oleh Hiro Tan mantan dosen di bidang ekonomi yang kemudian memutuskan untuk membuka usaha toko roti sendiri dengan menawarkan roti dengan model tempurung dan berkulit renyah dengan rasa mentega yang khas. Rotiboy menawarkan produk roti sebagai peluang usaha Franchise / Waralaba di Indonesia, Salah satu keuntungan waralaba rotiboy tidak diperlukan tempat yang besar. Karena area produksi tidak dilakukan di outlet, bahkan tidak ditampilkan.

Di Malaysia, rotiboy cukup diminati. Bahkan, ada beberapa toko roti yang mencoba meniru rasa dan bentuk yang mirip dengan srotiboy. Sasaran rotiboy berikutnya yaitu negaranegara luar meliputi Singapura, Thailand, Indonesia, dan Cina dan ini ditarik dari ahli melalui sistem waralaba yang kuat. Targetnya adalah untuk mencapai tingkat pertumbuhan $100 \%$ setiap bulan. Indonesia merupakan negara pertama yang memperoleh hak waralaba untuk memasarkan produk dan merek rotiboy.

Berdasarkan masalah diatas, maka tujuan penelitian ini adalah: Untuk melihat bagaimanakah pengaruh citra merek, kualitas produk, dan promosi terhadap kepuasan konsumen produk rotiboy di Kota Banda Aceh.

Pengaruh Citra Merek, Kualitas Produk dan Promosi Terhadap Kepuasan Konsumen Produk Rotiboy 


\section{METODOLOGI PENELITIAN}

Penelitian ini dilakukan di Kota Banda Aceh Provinsi Aceh. Objek penelitian adalah konsumen yang pernah mengkonsumsi produk rotiboy. Adapun ruang lingkup penelitian terbatas pada variabel-variabel yang mempengaruhi kepuasan konsumen produk rotiboy di Kota Banda Aceh. Adapun variabel-variabel yang menjadi fokus penelitian adalah kepuasan konsumen, citra merek (Brand Image), kualitas produk dan promosi.

\section{Metode dan Teknik Pengumpulan Data}

Metode yang digunakan dalam penelitian ini adalah metode survei. Metode survei adalah penyelidikan yang diadakan untuk memperoleh fakta-fakta dari gejala-gejala yang ada dan mencari keterangan secara faktual. Adapun populasi dalam penelitian ini adalah konsumen yaitu masyarakat Kota Banda Aceh yang pernah membeli dan mengkonsumsi produk rotiboy. Sampel yang diambil dalam penelitin ini menggunakan metode Accindental Sampling. Menurut Sugiyono (2004) Accindental Sampling adalah tehnik pengambilan sampel berdasarkan kebetulan yaitu siapa saja yang secara kebetulan bertemu bersama dengan peneliti dapat dijadikan sampel bila dipandang orang yang ditemui itu cocok sebagai sumber data. Sampel dalam penelitian ini berjumlah sebanyak 50 orang.

Jenis data yang digunakan dalam penelitian ini adalah data primer dan sekunder. Pengumpulan data primer di peroleh melalui kuisioner, wawancara dan observasi (pengamatan langsung) pada konsumen produk rotiboy. Sedangkan data sekunder diperoleh dari perpustakaan, jurnal serta informasi lain seperti hasil-hasil penelitian sebelumnya serta literatur yang berhubungan dengan penelitian.

\section{Teknik Analisis Data}

\section{Uji Validitas dan Reliabilitas}

\section{Uji Validitas}

Validitas adalah suatu ukuran yang menunjukkan tingkat kesahihan suatu kuisioner. Suatu instrumen dianggap valid atau sah apabila mampu mengukur apa yang diinginkan (Simamora, 2004). Untuk mengukur validitas dapat dilakukan dengan melakukan korelasi antar skor butir pertanyaan dengan total skor konstruk atau variabel. Penentuan validitas atas data kuisioner adalah yang memiliki nilai korelasi diatas tingkat derajat signifikan 5\%, sehingga pertanyaan dari item pertanyaan signifikan dan memiliki konsistensi internal yang berarti item-item pertanyaan tersebut dapat mengukur aspek yang sama.

\section{Uji Reliabilitas}

Uji reliabilitas adalah indeks yang menunjukkan apakah suatu alat ukur dapat dipercaya atau diandalkan, bila suatu alat ukur dipakai dua kali untuk mengukur gejala yang sama dan hasil pengukuran yang diperoleh relative konsisten maka alat ukur tersebut reliable. Menurut (Ghozali, 2011) Reliabiltas adalah alat untuk mengukur suatu kuisioner yang merupakan indikator dari variabel atau konstruk. Suatu kuisioner dikatakan reliabel atau handal apabila jawaban seseorang terhadap pertanyaan adalah konsisten atau stabil dari waktu ke waktu.Pengukuran reliabilitas dapat dilakukan dengan cara one shot atau pengukuran satu kali, dimana pengukuran hanya dilakukan sekali dan kemudian hasilnya dibandingkan dengan pertanyaan lain atau mengukur korelasi antar jawaban pertanyaan. SPSS memberikan fasilitas untuk mengukur reliabilitas dengan uji statistik Cronbach Alpha $(\alpha)$. Suatu konstruk atau variabel dikatakan reliabel jika memberikan nilai $(\alpha) 0,50$.

\section{Uji Asumsi Klasik}

\section{Uji Asumsi Heteroskedastitas}

Pengaruh Citra Merek, Kualitas Produk dan Promosi Terhadap Kepuasan Konsumen Produk Rotiboy 227 
Uji heteroskedastitas digunakan untuk menguji apakah dalam sebuah model regresi terjadi ketidaksamaan varians dari residual suatu pengamatan ke pengamatan yang lain. Jika varian dari residual dari suatu pengamatan ke pengamatan yang lain tetap, maka disebut homoskedastisitas. Dan jika varian berbeda disebut heteroskedasitas. Untuk mendeteksi gejala heteroskedastisitas, ada tidaknya pola yang terjadi pada nilai residu pada model, metode yang dapat digunakan adalah metode uji Glesjer. Uji Glesjer dilakukan dengan cara meregresikan antara variabel independent dengan nilai absolut residualnya. Jika nilai signifikansi antara variabel independent dengan nilai absolut residual lebih besar dari 0,05, maka dapat dipastikan model tidak mengandung unsur heteroskedastisitas.

\section{Uji Asumsi Multikolinieritas}

Uji multikolinieritas digunakan untuk mengetahui ada tidaknya kolerasi antara variabel independent, jika terjadi kolerasi maka terdapat problem multikolonieritas. Suliyanto (2005: 63) menyatakan bahwa jika pada model regresi mengandung gejala multikolonieritas berarti terjadi korelasi (mendekati sempurna) antarvariabel bebas. Untuk mengetahui ada tidaknya multikolinieritas antar variabel, dapat dilihat dari nilai variance inflation factor (VIF) dari masing-masing variabel bebas terdapat variabel terikat. Jika nilai VIF lebih kecil dari 5, maka model tidak terdapat multikolonieritas, artinya tidak adanya hubungan antarvariabel bebas.

\section{Uji Asumsi Normalitas}

Uji normalitas dimaksudkan untuk mengecek apakah data penelitian kita berasal dari populasi yang sebarannya normal atau tidak. Uji normalitas bertujuan untuk mengetahui nilai acak dari tiap variabel independent dan variabel dependent karena model regresi yang baik harus mengikuti distribusi normal atau mendekati normal. Distribusi data tidak normal, karena terdapat nilai ekstrem dalam data. Dalam penelitian ini jenis uji normalitas yang digunakan yaitu melalui pengujian SPSS dengan menggunakan uji Shapiro Wilk. Uji statistik non parametrik Shapiro Wilk dilakukan dengan melihat nilai signifikansi dari masing-masing variabel. Jika nilai signifikansi dari masing-masing variabel $>0,05$ maka dapat dikatakan data berdistibusi normal.

\section{Analisis Regresi Linier Berganda}

Regresi linier berganda berfungsi untuk mengetahui pengaruh atau hubungan variabel bebas (citra merek, kualitas produk dan promosi) dan variabel terikat (kepuasan konsumen). Regresi linier berganda adalah pengujian analisis statistik yang mempelajari pola hubungan antara dua atau lebih variabel yang di formulasikan secara matematis sebagai berikut :

$$
\mathrm{Y}=\mathrm{a}+\mathrm{b}_{1} \mathrm{X}_{1}+\mathrm{b}_{2} \mathrm{X}_{2}+\mathrm{b}_{3} \mathrm{X}_{3}+\mathrm{e} \ldots(\text { Nasir, 2003) }
$$

Dimana :

$\mathrm{Y}=$ Kepuasan Konsumen

$\mathrm{a}=$ Konstanta

$\mathrm{b}_{1}-\mathrm{b}_{3}=$ Koefisien Regresi (skor)

$\mathrm{X}_{1}=$ Citra Merek

$\mathrm{X}_{2}=$ Kualitas Produk

$\mathrm{X}_{3}=$ Promosi

$\mathrm{e}=$ Standard eror/hambatan 


\section{Uji F (Uji Serempak)}

Uji $\mathrm{F}$ digunakan untuk menguji pengaruh variabel bebas yaitu citra merek $\left(\mathrm{X}_{1}\right)$, kualitas produk $\left(\mathrm{X}_{2}\right)$ dan promosi $\left(\mathrm{X}_{3}\right)$ secara bersama-sama terhadap variabel terikat yaitu kepuasan konsumen (Y). Melalui uji statistik dengan menggunakan langkah-langkah sebagai berikut :

$\mathrm{H}_{0}: \mathrm{b}_{1}=\mathrm{b}_{2}=\mathrm{b}_{3}=0$

Artinya, tidak terdapat pengaruh yang positif dan signifikan dari variabel bebas yaitu citra merek (X1), kualitas produk (X2), dan promosi (X3) secara simultan terhadap variabel terikat yaitu kepuasan konsumen $(\mathrm{Y})$.

$\mathrm{Ha}: \mathrm{b}_{1} \neq \mathrm{b}_{2} \neq \mathrm{b}_{3} \neq 0$

Artinya, terdapat pengaruh yang positif dan signifikan dari variabel bebas yaitu citra merek (X1), kualitas produk (X2) dan promosi (X3) secara simultan terhadap variabel terikat yaitu kepuasan konsumen (Y).

Kriteria pengambilan keputusan yaitu :

$\mathrm{H}_{0}$ diterima, apabila $\mathrm{F}_{\text {hitung }}<\mathrm{F}_{\text {tabel }}$

Ha diterima, apabila $F_{\text {hitung }}>F_{\text {tabel }}$

\section{Uji t (Uji Parsial)}

Uji t digunakan untuk menguji signifikansi konstanta dari setiap variabelbebas, apakah citra merek (X1), kualitas produk (X2) dan promosi (X3) benar-benar berpengaruh secara parsial(terpisah) terhadap variabel terikatnya yaitu kepuasan konsumen (Y). Melalui uji t (uji parsial) dengan menggunakan langkah-langkah sebagai berikut : $\mathrm{H}_{0}: \mathrm{b}_{1}=0$

Artinya, tidak terdapat pengaruh yang positif dan signifikan dari variabel bebas yaitu citra merek (X1), kualitas produk (X2), dan promosi (X3) secara parsial terhadap variabel terikat yaitu kepuasan konsumen (Y). Ha : $\mathrm{b}_{1} \neq 0$

Artinya, terdapat pengaruh yang positif dan signifikan dari variabel bebas yaitu citra merek (X1), kualitas produk (X2) dan promosi (X3) secara parsial terhadap variabel terikat yaitu kepuasan konsumen (Y). Kriteria pengambilan keputusan yaitu :

$\mathrm{H}_{0}$ diterima, apabila $\mathrm{t}_{\text {hitung }}<\mathrm{t}_{\text {tabel }}$

Ha diterima, apabila $t_{\text {hitung }}>t_{\text {tabel }}$

\section{HASIL DAN PEMBAHASAN}

\section{Deskriptif Kepuasan Konsumen Rotiboy}

Dari hasil penelitian yang telah dilakukan terhadap 50 orang konsumen rotiboy yang ada di Kota Banda Aceh maka dapat dilihat tingkat kepuasan konsumen terhadap rotiboy seperti yang disajikan dalam beberapa grafik dibawah ini.

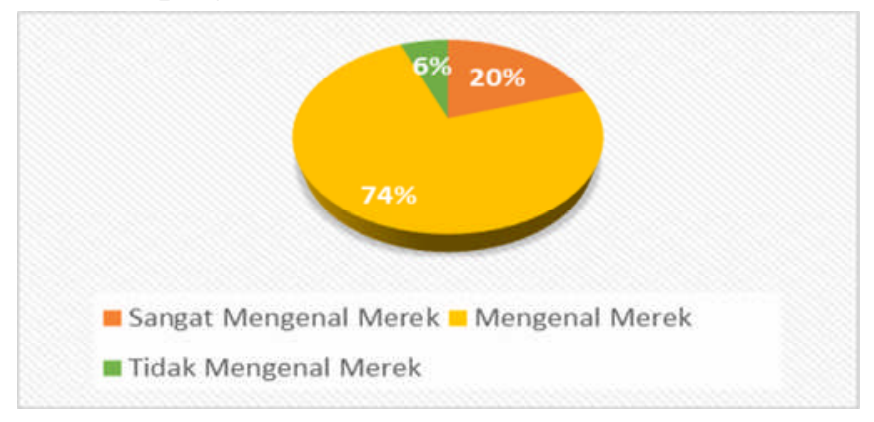

Pengaruh Citra Merek, Kualitas Produk dan Promosi Terhadap Kepuasan Konsumen Produk Rotiboy 


\section{Gambar 1. Memilih Produk Rotiboy Dikarenakan Merek}

Berdasarkan gambar 1 diatas, dapat dilihat bahwa $74 \%$ responden memilih produk rotiboy dikarenakan mengenal merek dan $20 \%$ responden memilih produk rotiboy dikarenakan sangat mengenal merek sedangkan sisanya $6 \%$ responden memilih produk rotiboy tanpa mengenal merek. Jadi dapat disimpulkan bahwa sebagian besar responden memilih produk rotiboy karena mengenal merek yaitu sebesar $84 \%$.

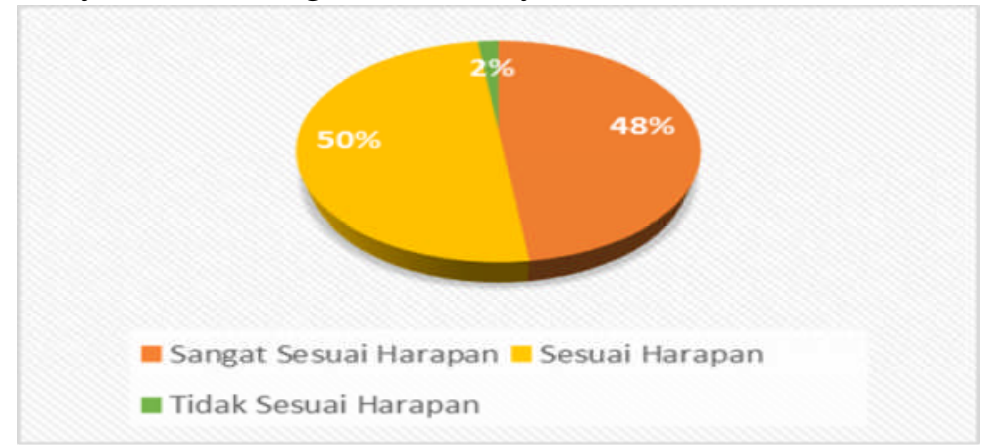

Gambar 2. Citarasa Produk Rotiboy

Pada gambar 2 ini dapat diketahui bahwa sebagian besar responden yang telah membeli rotiboy menyatakan bahwa citarasa dari produk rotiboy ini sesuai dengan harapan. Yaitu dapat dilihat pada gambar diatas bahwa $50 \%$ responden mengatakan citarasa rotiboy sesuai dengan harapan mereka dan $48 \%$ mengatakan citarasa rotiboy sangat sesuai dengan harapan sedangkan sisanya hanya $2 \%$ dari responden yang mengatakan citarasa rotiboy tidak sesuai dengan harapan.

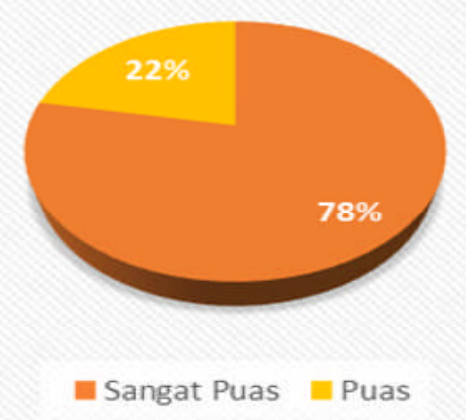

\section{Gambar 3. Kepuasan Konsumen Terhadap Rotiboy}

Berdasarkan gambar 3, dapat diketahui bahwa responden merasa puas terhadap kualitas produk rotiboy. Dimana dapat dilihat pada gambar tersebut bahwa $78 \%$ responden mengatakan sangat puas terhadap kualitas produk rotiboy dan $22 \%$ responden mengatakan puas terhadap kualitas produk rotiboy.

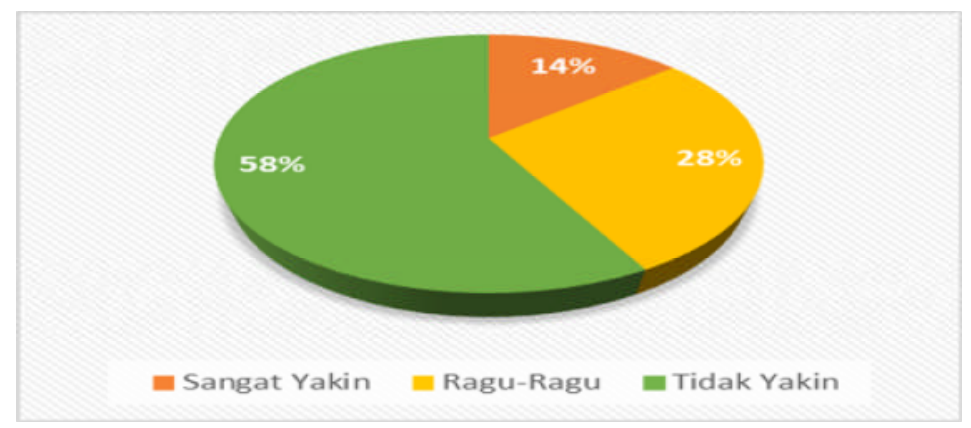

Pengaruh Citra Merek, Kualitas Produk dan Promosi Terhadap Kepuasan Konsumen Produk Rotiboy 


\section{Gambar 4. Pandangan Konsumen Tentang Persaingan Rotiboy dengan Roti Merek Lain}

Dari gambar 4 diatas dapat diketahui bahwa $58 \%$ responden rotiboy berpendapat bahwa, konsumen tidak yakin rotiboy dapat bertahan dari persaingan dengan merek yang lain (untuk produk sejenis). Sedangkan $28 \%$ responden rotiboy berpendapat bahwa kurang yakin (raguragu) rotiboy dapat bertahan dari persaingan dengan merek yang lain (untuk produk sejenis) dan $14 \%$ berpendapat bahwa sangat yakin rotiboy dapat bertahan dari persaingan dengan merek yang lain (untuk produk sejenis). Jadi dapat disimpulkan bahwa sebagian besar responden dari total keseluruhan responden yang diteliti berpendapat bahwa responden tidak yakin rotiboy dapat bertahan dari persaingan dengan merek yang lain (untuk produk sejenis).

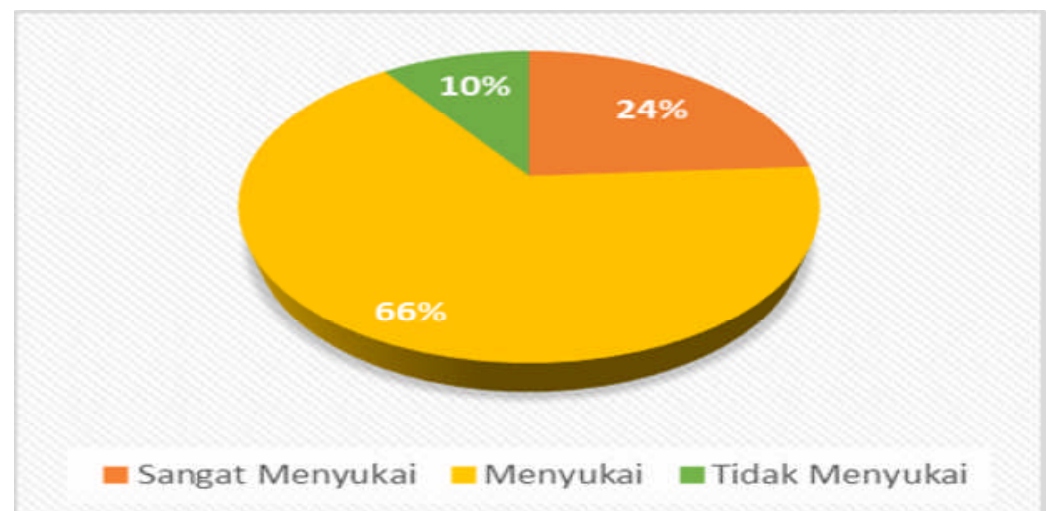

\section{Gambar 5. Persepsi Responden Mengenai Rotiboy dengan Merek Lain}

Berdasarkan gambar diatas, dapat dilihat bahwa 66\% responden menyukai rotiboy dibandingkan dengan merek yang lain. Dan $24 \%$ responden sangat menyukai rotiboy dibandingkan dengan merek yang lain. Sedangkan sisanya $10 \%$ responden tidak menyukai rotiboy dibandingkan dengan merek yang lain.

\section{Deskriptif Kepuasan Konsumen Rotiboy Berdasarkan Kategori Jenis Kelamin,}

\section{Usia, Profesi, Pendidikan dan Penghasilan}

Dari hasil penelitian yang telah dilakukan terhadap 50 orang konsumen rotiboy yang ada di Kota Banda Aceh, dimana setiap responden memiliki karakteristik yang terdiri dari jenis kelamin, usia, pekerjaan, pendidikan dan penghasilan rata-rata/bulan yang diterima. Maka dapat dilihat tingkat kepuasan konsumen terhadap rotiboy berdasarkan karakteristik responden seperti yang disajikan dalam beberapa tabel dibawah ini.

Tabel 1. Tingkat Kepuasan Konsumen Rotiboy Berdasarkan Jenis Kelamin

\begin{tabular}{|c|c|c|c|c|c|c|}
\hline \multirow{2}{*}{ No. } & \multirow{2}{*}{\multicolumn{2}{|c|}{ JenisKelamin }} & \multicolumn{3}{|c|}{ KepuasanKonsumen } & \multirow{2}{*}{ Total } \\
\hline & & & Kurang Puas & Puas & Sangat Puas & \\
\hline \multirow{2}{*}{1.} & \multirow{2}{*}{ Laki-laki } & Frekuensi & 2 & 14 & 0 & 16 \\
\hline & & $\%$ & $4 \%$ & $28 \%$ & $0 \%$ & $32 \%$ \\
\hline \multirow{2}{*}{2.} & \multirow{2}{*}{ Perempuan } & Frekuensi & 5 & 27 & 2 & 34 \\
\hline & & $\%$ & $10 \%$ & $54 \%$ & $4 \%$ & $68 \%$ \\
\hline & \multirow{2}{*}{ Total } & Frekuensi & 7 & 41 & 2 & 50 \\
\hline & & $\%$ & $14 \%$ & $82 \%$ & $4 \%$ & $100 \%$ \\
\hline
\end{tabular}

Sumber : Data Primer (diolah), 2016

Dari tabel 1 diketahui bahwa tingkat kepuasan konsumen rotiboy berdasarkan jenis kelamin terdiri dari sangat puas, puas dan kurang puas. Dimana untuk responden yang 
berjenis kelamin laki-laki dengan tingkat kepuasan kurang puas sebanyak 2 orang dengan persentase $4 \%$, sedangkan untuk tingkat kepuasan puas terhadap rotiboy yaitu sebanyak 14 orang dengan persentase $28 \%$. Kemudian untuk responden yang berjenis kelamin perempuan dengan tingkat kepuasan kurang puas sebanyak 5 orang dengan persentase $10 \%$, sedangkan untuk tingkat kepuasan puas terhadap rotiboy yaitu sebanyak 27 orang dengan persentase $54 \%$. Dan untuk tingkat kepuasan sangat puas terhadap rotiboy yaitu sebanyak 2 orang dengan persentase $4 \%$.

Tabel 2. Tingkat Kepuasan Konsumen Rotiboy Berdasarkan Usia

\begin{tabular}{|c|c|c|c|c|c|c|}
\hline \multirow{2}{*}{ No. } & \multirow{2}{*}{\multicolumn{2}{|c|}{ Usia (Tahun) }} & \multicolumn{3}{|c|}{ KepuasanKonsumen } & \multirow{3}{*}{$\begin{array}{c}\text { Total } \\
10\end{array}$} \\
\hline & & & \multirow{2}{*}{$\begin{array}{c}\text { Kurang Puas } \\
1 \\
\end{array}$} & \multirow{2}{*}{$\begin{array}{c}\text { Puas } \\
8\end{array}$} & \multirow{2}{*}{$\begin{array}{c}\text { Sangat Puas } \\
1\end{array}$} & \\
\hline \multirow{2}{*}{1.} & \multirow{2}{*}{$13-18$} & Frekuensi & & & & \\
\hline & & $\%$ & $2,0 \%$ & $16,0 \%$ & $2,0 \%$ & $20,0 \%$ \\
\hline \multirow{2}{*}{2.} & \multirow{2}{*}{$19-24$} & Frekuensi & 3 & 15 & 0 & 18 \\
\hline & & $\%$ & $6,0 \%$ & $30,0 \%$ & $0,0 \%$ & $36,0 \%$ \\
\hline \multirow{2}{*}{3.} & \multirow{2}{*}{$25-29$} & Frekuensi & 0 & 6 & 1 & 7 \\
\hline & & $\%$ & $0,0 \%$ & $12,0 \%$ & $2,0 \%$ & $14,0 \%$ \\
\hline \multirow{2}{*}{4.} & \multirow{2}{*}{$>30$} & Frekuensi & 3 & 12 & 0 & 15 \\
\hline & & $\%$ & $6,0 \%$ & $24,0 \%$ & $0,0 \%$ & $30,0 \%$ \\
\hline \multirow{2}{*}{\multicolumn{2}{|c|}{ Total }} & Frekuensi & 7 & 41 & 2 & 50 \\
\hline & & $\%$ & $14,0 \%$ & $82,0 \%$ & $4,0 \%$ & $100,0 \%$ \\
\hline
\end{tabular}

Sumber : Data Primer (diolah), 2016

Berdasarkan tabel 2 diatas, dapat dilihat bahwa tingkat kepuasan konsumen yang terbanyak adalah responden dengan tingkat kepuasan puas terhadap rotiboy. Yaitu dengan frekuensi sebanyak 41 orang dengan persentase sebesar $82 \%$. Dari 41 orang tersebut sebagian besarnya adalah responden dengan rentang usia 19-24 tahun dan responden dengan usia >30 tahun. Sedangkan untuk tingkat kepuasan kurang puas terhadap rotiboy hanya sebesar $14 \%$ dengan frekuensi 7 orang. Dan untuk tingkat kepuasan sangat puas terhadap rotiboy hanya sebesar 4\% dengan frekuensi 2 orang. Seperti yang terlihat pada tabel 2 diatas.

Tabel 3. Tingkat Kepuasan Konsumen Rotiboy Berdasarkan Profesi

\begin{tabular}{|c|c|c|c|c|c|c|}
\hline \multirow{2}{*}{ No. } & \multirow{2}{*}{\multicolumn{2}{|c|}{ Profesi }} & \multicolumn{3}{|c|}{ KepuasanKonsumen } & \multirow{3}{*}{$\begin{array}{c}\text { Total } \\
26 \\
\end{array}$} \\
\hline & & & Kurang Puas & Puas & Sangat Puas & \\
\hline \multirow{2}{*}{1.} & \multirow{2}{*}{ Pelajar/Mahasiswa } & Frekuensi & 3 & 22 & 1 & \\
\hline & & $\%$ & $6,0 \%$ & $44,0 \%$ & $2,0 \%$ & $52,0 \%$ \\
\hline \multirow{2}{*}{2.} & \multirow{2}{*}{ PNS } & Frekuensi & 0 & 4 & 0 & 4 \\
\hline & & $\%$ & $0,0 \%$ & $8,0 \%$ & $0,0 \%$ & $8,0 \%$ \\
\hline \multirow{2}{*}{3.} & \multirow{2}{*}{ Wiraswasta } & Frekuensi & 0 & 7 & 0 & 7 \\
\hline & & $\%$ & $0,0 \%$ & $14,0 \%$ & $0,0 \%$ & $14,0 \%$ \\
\hline \multirow{2}{*}{4.} & \multirow{2}{*}{ IRT } & Frekuensi & 2 & 5 & 1 & 8 \\
\hline & & $\%$ & $4,0 \%$ & $10,0 \%$ & $2,0 \%$ & $16,0 \%$ \\
\hline \multirow{2}{*}{5.} & \multirow{2}{*}{ Lainnya } & Frekuensi & 2 & 3 & 0 & 5 \\
\hline & & $\%$ & $4,0 \%$ & $6,0 \%$ & $0,0 \%$ & $10,0 \%$ \\
\hline \multirow{2}{*}{\multicolumn{2}{|c|}{ Total }} & Frekuensi & 7 & 41 & 2 & 50 \\
\hline & & $\%$ & $14,0 \%$ & $82,0 \%$ & $4,0 \%$ & $100,0 \%$ \\
\hline
\end{tabular}

Sumber:Data Primer (diolah), 2016

Berdasarkan tabel 3 diatas, dapat dilihat bahwa tingkat kepuasan untuk responden yang berprofesi sebagai pelajar/mahasiswa adalah sebesar 52\% dengan frekuensi 26 orang 
yang terdiri dari 22 orang dengan persentase $44 \%$ yang merasakan puas terhadap rotiboy, 3 orang dengan persentase $6 \%$ yang merasakan kurang puas terhadap rotiboy, dan 1 orang dengan persentase $2 \%$ yang merasakan sangat puas terhadap rotiboy. Kemudian untuk responden yang berprofesi sebagai IRT adalah sebesar $16 \%$, responden yang berprofesi sebagai wiraswasta adalah sebesar 14\%, responden yang berprofesi lainnya sebesar $10 \%$, dan responden yang berprofesi sebagai PNS sebesar $8 \%$. Seperti yang terlihat pada tabel 3 diatas. Tabel 4.Tingkat Kepuasan Konsumen Rotiboy Berdasarkan Tingkat Pendidikan

\begin{tabular}{|c|c|c|c|c|c|c|}
\hline \multirow{2}{*}{ No. } & \multirow{2}{*}{\multicolumn{2}{|c|}{ PendidikanTerakhir }} & \multicolumn{3}{|c|}{ KepuasanKonsumen } & \multirow{3}{*}{$\begin{array}{c}\text { Total } \\
10\end{array}$} \\
\hline & & & \multirow{2}{*}{$\frac{\text { Kurang Puas }}{1}$} & \multirow{2}{*}{$\begin{array}{c}\text { Puas } \\
8\end{array}$} & \multirow{2}{*}{$\frac{\text { Sangat Puas }}{1}$} & \\
\hline \multirow{2}{*}{1.} & \multirow{2}{*}{ SMP } & Frekuensi & & & & \\
\hline & & $\%$ & $2,0 \%$ & $16,0 \%$ & $2,0 \%$ & $20,0 \%$ \\
\hline \multirow{2}{*}{2.} & \multirow{2}{*}{ SMA } & Frekuensi & 3 & 23 & 0 & 26 \\
\hline & & $\%$ & $6,0 \%$ & $46,0 \%$ & $0,0 \%$ & $52,0 \%$ \\
\hline \multirow{2}{*}{3.} & \multirow{2}{*}{ S1 } & Frekuensi & 2 & 4 & 0 & 6 \\
\hline & & $\%$ & $4,0 \%$ & $8,0 \%$ & $0,0 \%$ & $12,0 \%$ \\
\hline \multirow{2}{*}{4.} & \multirow{2}{*}{ Lainnya } & Frekuensi & 1 & 6 & 1 & 8 \\
\hline & & $\%$ & $2,0 \%$ & $12,0 \%$ & $2,0 \%$ & $16,0 \%$ \\
\hline \multirow{2}{*}{\multicolumn{2}{|c|}{ Total }} & Frekuensi & 7 & 41 & 2 & 50 \\
\hline & & $\%$ & $14,0 \%$ & $82,0 \%$ & $4,0 \%$ & $100,0 \%$ \\
\hline
\end{tabular}

Sumber : Data Primer (diolah), 2016

Berdasarkan tabel 4 diatas, dapat dilihat bahwa tingkat kepuasan untuk responden dengan pendidikan terakhir SMA adalah sebesar 52\% dengan frekuensi 26 orang yang terdiri dari 23 orang dengan persentase $46 \%$ yang merasakan puas terhadap rotiboy dan 3 orang dengan persentase $6 \%$ yang merasakan kurang puas terhadap rotiboy. Kemudian untuk responden dengan pendidikan terakhir SMP adalah sebesar 20\%, responden dengan pendidikan terakhir lainnya adalah sebesar $16 \%$, dan responden dengan pendidikan terakhir S1 adalah sebesar $12 \%$. Seperti yang terlihat pada tabel 4 diatas.

Tabel 5. Tingkat Kepuasan Konsumen Rotiboy Berdasarkan Penghasilan Rata-rata/bulan

\begin{tabular}{|c|c|c|c|c|c|c|}
\hline \multirow{2}{*}{ No. } & \multirow{2}{*}{\multicolumn{2}{|c|}{$\begin{array}{l}\text { Pengahasilan Rata- } \\
\text { rata/bulan (Rupiah) }\end{array}$}} & \multicolumn{3}{|c|}{ KepuasanKonsumen } & \multirow{3}{*}{$\begin{array}{c}\text { Total } \\
30 \\
\end{array}$} \\
\hline & & & \multirow{2}{*}{$\begin{array}{c}\text { Kurang Puas } \\
4 \\
\end{array}$} & \multirow{2}{*}{$\begin{array}{c}\text { Puas } \\
24 \\
\end{array}$} & \multirow{2}{*}{$\frac{\text { Sangat Puas }}{2}$} & \\
\hline \multirow{2}{*}{1.} & \multirow{2}{*}{$<1.500 .000$} & Frekuensi & & & & \\
\hline & & $\%$ & $8,0 \%$ & $48,0 \%$ & $4,0 \%$ & $60,0 \%$ \\
\hline \multirow{2}{*}{2.} & \multirow{2}{*}{$\begin{array}{l}1.500 .000- \\
2.499 .999\end{array}$} & Frekuensi & 1 & 8 & 0 & 9 \\
\hline & & $\%$ & $2,0 \%$ & $16,0 \%$ & $0,0 \%$ & $18,0 \%$ \\
\hline \multirow{2}{*}{3.} & \multirow{2}{*}{$\begin{array}{l}2.500 .000- \\
3.499 .999 \\
\end{array}$} & Frekuensi & 2 & 6 & 0 & 8 \\
\hline & & $\%$ & $4,0 \%$ & $12,0 \%$ & $0,0 \%$ & $16,0 \%$ \\
\hline \multirow{2}{*}{4.} & \multirow{2}{*}{$\begin{array}{l}3.500 .000- \\
4.499 .999\end{array}$} & Frekuensi & 0 & 3 & 0 & 3 \\
\hline & & $\%$ & $0,0 \%$ & $6,0 \%$ & $0,0 \%$ & $6,0 \%$ \\
\hline & \multirow{2}{*}{ Total } & Frekuensi & 7 & 41 & 2 & 50 \\
\hline & & $\%$ & $14,0 \%$ & $82,0 \%$ & $4,0 \%$ & $100,0 \%$ \\
\hline
\end{tabular}

Sumber : Data Primer (diolah), 2016

Berdasarkan tabel 5 diatas, dapat dilihat bahwa tingkat kepuasan untuk responden dengan penghasilan rata-rata/bulan sebesar < Rp.1.500.000 adalah sebesar 60\% dengan frekuensi 30 orang yang terdiri dari 24 orang dengan persentase $48 \%$ yang merasakan puas terhadap rotiboy, 4 orang dengan persentase $8 \%$ yang merasakan kurang puas terhadap rotiboy dan 2 orang dengan persentase $4 \%$ yang merasakan sangat puas terhadap rotiboy. Kemudian untuk responden dengan penghasilan rata-rata/bulan sebesar Rp.1.500.000- 
2.499.999 adalah sebesar $18 \%$, responden dengan penghasilan rata-rata/bulan sebesar Rp. 2.500.000-3.499.999 adalah sebesar 16\%, dan responden dengan penghasilan rata-rata/bulan sebesar Rp.3.500.000-4.499.999 adalah sebesar 6\%. Seperti yang terlihat pada tabel 5 diatas.

\section{Uji Regresi Linier Berganda}

Regresi linier berganda bertujuan untuk mengetahui pengaruh atau hubungan variabel bebas (citra merek, kualitas produk dan promosi) dan variabel terikat (kepuasan konsumen). Kepuasan konsumen dapat disebabkan oleh faktor citra merek, kualitas produk dan promosi. Ketiga variabel ini berpengaruh terhadap kepuasan konsumen. Hal ini dapat dilihat dari hasil nilai koefisien regresi masing-masing variabel yang ditunjukkan pada tabel berikut.

Tabel 6. Hasil Uji Regresi Linier Berganda

\begin{tabular}{|l|c|c|c|c|}
\hline \multicolumn{1}{|c|}{ Nama Variabel } & B & Standar Error & t Hitung & Sig. \\
\hline Konstanta & 2,330 & 4,901 & 0,475 & 0,639 \\
\hline Citra Merek & 0,295 & 0,133 & 2,217 & 0,037 \\
\hline Kualitasproduk & 0,300 & 0,158 & 1,892 & 0,072 \\
\hline Promosi & 0,273 & 0,202 & 1,351 & 0,190 \\
\hline
\end{tabular}

Sumber : Data Primer (diolah), 2016

Dari hasil perhitungan statistik dengan menggunakan bantuan komputer melalui program SPSS seperti yang terlihat pada tabel 6, maka diperoleh persamaan regresi linier berganda sebagai berikut :

$\mathrm{Y}=2,330+0,295 \mathrm{X}_{1}+0,300 \mathrm{X}_{2}+0,273 \mathrm{X}_{3}$

Dari persamaan regresi tersebut dapat diketahui hasil penelitian sebagai berikut :

a) Dalam penelitian ini diperoleh nilai konstanta sebesar 2,330. Artinya jika citra merek $\left(\mathrm{X}_{1}\right)$, kualitas Produk $\left(\mathrm{X}_{2}\right)$ dan promosi $\left(\mathrm{X}_{3}\right)$ dianggap konstan maka besarnya kepuasan konsumen rotiboy di Kota Banda Aceh adalah sebesar 2,330.

b) Koefisien regresi citra merek $\left(X_{1}\right)$ sebesar 0,295. Artinya setiap perubahan dalam satu unit variabel citra merek maka secara relatif akan meningkatkan kepuasan konsumen rotiboy di Kota Banda Aceh sebesar 0,295 dengan asumsi variabel lain dianggap konstan.

c) Koefisien regresi kualitas Produk $\left(\mathrm{X}_{2}\right)$ sebesar 0,300. Artinya setiap perubahan dalam satu unit variabel kualitas produk maka secara relatif akan meningkatkan kepuasan konsumen rotiboy di Kota Banda Aceh sebesar 0,300. Dengan demikian semakin konsumen merasa puas dengan kualitas produk yang diberikan, maka secara relatif akan meningkatkan kepuasan konsumen.

d) Koefisien regresi promosi $\left(\mathrm{X}_{3}\right)$ sebesar 0,273. Artinya setiap perubahan dalam satu unit variabel promosi maka secara relatif akan meningkatkan kepuasan konsumen rotiboy di Kota Banda Aceh sebesar 0,273.

Dari output SPSS regresi linier berganda juga didapat koefisien korelasi dan determinasi yang menjelaskan hubungan antara variabel penelitian seperti yang dijelaskan pada tabel 7.

Tabel 7. Koefisien Korelasi dan Determinasi

Model Summary

\begin{tabular}{|l|c|r|r|r|}
\hline Model & \multicolumn{1}{|c|}{$\mathrm{R}$} & $\mathrm{R}$ Square & Adjusted R Square & \multicolumn{2}{|c|}{ Std. Error of the Estimate } \\
\hline 1 & $0,649^{\mathrm{a}}$ & 0,421 & 0,342 & \\
\hline
\end{tabular}

Sumber : Data Primer (diolah), 2016 
Berdasarkan hasil perhitungan hubungan korelasi seperti yang terlihat pada tabel 7 , variabel citra merek $\left(\mathrm{X}_{1}\right)$, kualitas Produk $\left(\mathrm{X}_{2}\right)$ dan promosi $\left(\mathrm{X}_{3}\right)$ dengan kepuasan konsumen rotiboy di Kota Banda Aceh diperoleh koefisien korelasi sebesar 0,649, dimana dengan nilai tersebut berarti terdapat hubungan antar variabel bebas dengan variabel terikat sebesar $64,9 \%$. Sedangkan koefisien determinasi diperoleh nilai sebesar 0,421 yang berarti bahwa sebesar $42,1 \%$ perubahan-perubahan dalam variabel terikat (kepuasan konsumen) dapat dijelaskan oleh perubahan-perubahan dalam variabel citra merek $\left(\mathrm{X}_{1}\right)$, kualitas produk $\left(\mathrm{X}_{2}\right)$ dan promosi $\left(\mathrm{X}_{3}\right)$. Sedangkan selebihnya yaitu $57,9 \%$ dijelaskan oleh faktor lain diluar variabel yang dijadikan indikator variabel penelitian, hal ini mengindikasikan bahwa masih ada sebesar $57,9 \%$ faktor kepuasan konsumen dipengaruhi oleh faktor lain, selain dari citra merek, kualitas produk dan promosi.

\section{Pembuktian Hipotesis}

\section{Secara Serempak}

Untuk melihat besarnya pengaruh secara keseluruhan terhadap variabel yang diteliti maka akan diuji berdasarkan uji ANOVA seperti dijelaskan pada tabel berikut ini.

Tabel 8. Analisis of Variance (ANOVA)

\begin{tabular}{|l|c|c|c|c|c|c|}
\hline Model & $\begin{array}{c}\text { Sum of } \\
\text { Squares }\end{array}$ & Df & $\begin{array}{l}\text { Mean } \\
\text { Square }\end{array}$ & f Hitung & f Tabel & Sig. \\
\hline Regression & 28,766 & 3 & 9,589 & 5,330 & 3,05 & 0,007 \\
\hline Residual & 39,580 & 22 & 1,799 & & & \\
\hline Total & 68,346 & 25 & & & & \\
\hline
\end{tabular}

Sumber : Data Primer (diolah), 2016

Berdasarkan dari hasil uji ANOVA atau uji $\mathrm{F}$ (secara serempak) diperoleh $\mathrm{F}_{\text {hitung }}$ sebesar 5,330, sedangkan $\mathrm{F}_{\text {tabel }}$ pada tingkat signifikansi $\alpha=5 \%$ adalah sebesar 3,05. Hal ini memperlihatkan bahwa $\mathrm{F}_{\text {hitung }}>\mathrm{F}_{\text {tabel }}(5,330>3,05)$, dengan tingkat signifikansi 0,007. Dari hasil perhitungan ini dapat diambil suatu kesimpulan bahwa menerima $\mathrm{Ha}$ dan menolak Ho, artinya bahwa variabel citra merek, kualitas produk dan promosi secara bersama-sama atau simultan berpengaruh secara signifikan terhadap kepuasan konsumen rotiboy di Kota Banda Aceh.

\section{Secara Parsial}

Tabel 9. Hasil Uji T

\begin{tabular}{|l|c|c|c|c|c|}
\hline Nama Variabel & B & $\begin{array}{c}\text { Standar } \\
\text { Error }\end{array}$ & t Hitung & t Tabel & Sig. \\
\hline Konstanta & 2,330 & 4,901 & 0,475 & & 0,639 \\
\hline Citra Merek & 0,295 & 0,133 & 2,217 & \multirow{2}{*}{1,717} & 0,037 \\
\cline { 1 - 4 } KualitasProduk & 0,300 & 0,158 & 1,892 & & 0,072 \\
\hline Promosi & 0,273 & 0,202 & 1,351 & & 0,190 \\
\hline
\end{tabular}

Sumber : Data Primer (diolah), 2016

\section{Pengaruh Citra Merek Terhadap Kepuasan Konsumen}

Secara parsial citra merek berpengaruh positif terhadap kepuasan konsumen. Hal ini ditunjukkan oleh koefisien regresi untuk variabel citra merek sebesar 0,295. Hasil pengujian statistik menunjukkan nilai t hitung untuk citra merek sebesar 2,217 dengan nilai signifikansi 
sebesar 0,037. Sedangkan nilai t tabel sebesar 1,717. Karena nilai t hitung > t tabel $(2,217>$ 1,717) maka hipotesis Ha diterima dan sebaliknya hipotesis Ho ditolak yang berarti citra merek berpengaruh signifikansi terhadap kepuasan konsumen rotiboy di Kota Banda Aceh. Artinya variabel citra merek memberikan pengaruh yang signifikan kepada konsumen saat melakukan pembelian terhadap suatu produk. Semakin bagus citra merek dari suatu produk maka akan semakin bagus kesan dari merek produk tersebut di mata konsumen dan pada akhirnya akan mempengaruhi kepuasan konsumen terhadap produk tersebut.

\section{Pengaruh Kualitas Produk Terhadap Kepuasan Konsumen}

Secara parsial kualitas produk berpengaruh positif terhadap kepuasan konsumen. Hal ini ditunjukkan oleh koefisien regresi untuk variabel kualitas produk sebesar 0,300. Hasil pengujian statistik menunjukkan nilai t hitung untuk kualitas produk sebesar 1,892 dengan nilai signifikansi sebesar 0,072 . Sedangkan nilai t tabel sebesar 1,717 . Karena nilai t hitung > t tabel $(1,892>1,717)$ maka hipotesis Ha diterima dan sebaliknya hipotesis Ho ditolak yang berarti kualitas produk berpengaruh signifikansi terhadap kepuasan konsumen rotiboy di Kota Banda Aceh. Artinya variabel kualitas produk mempengaruhi konsumen saat membeli rotiboy. Konsumen akan melihat bagaimana kualitas dari roti tersebut sebelum akhirnya memutuskan untuk membeli produk tersebut. Sehingga dapat dikatakan kualitas produk yang baik akan mempengaruhi kepuasan konsumen. Semakin bagus kualitas dari suatu produk maka akan semakin meningkatkan kepuasan konsumen terhadap produk tersebut.

\section{Pengaruh Promosi Terhadap Kepuasan Konsumen}

Secara parsial promosi tidak berpengaruh positif terhadap kepuasan konsumen. Hal ini ditunjukkan oleh koefisien regresi untuk variabel promosi sebesar 0,273. Hasil pengujian statistik menunjukkan nilai t hitung untuk promosi sebesar 1,351 dengan nilai signifikansi sebesar 0,190. Sedangkan nilai $t$ tabel sebesar 1,717. Karena nilai $t$ hitung < t tabel $(1,351<$ 1,717) maka hipotesis Ha ditolak dan sebaliknya hipotesis Ho diterima yang berarti promosi tidak berpengaruh signifikansi terhadap kepuasan konsumen rotiboy di Kota Banda Aceh. Artinya variabel promosi dalam penelitian ini tidak mempengaruhi konsumen dalam membuat keputusan saat membeli rotiboy dan tidak berpengaruh terhadap kepuasan konsumen terhadap produk tersebut.

\section{KESIMPULAN DAN SARAN}

Berdasarkan analisis data dan pembahasan yang telah dikemukakan pada bab sebelumnya, maka dapat ditarik beberapa kesimpulan penelitian sebagai berikut: Variabel kualitas produk memiliki pengaruh lebih besar terhadap kepuasan konsumen dibandingkan variabel citra merek dan promosi dengan hasil regresi sebesar 0,300. Selanjutnya pengaruh variabel lainnya yaitu citra merek adalah sebesar 0,295 dan promosi adalah sebesar 0,273. Secara serempak variabel citra merek, kualitas produk dan promosi berpengaruh positif atau signifikan terhadap kepuasan konsumen rotiboy di Kota Banda Aceh. Dimana $\mathrm{F}_{\text {hitung }}>\mathrm{F}_{\text {tabel }}$ $(5,330>3,05)$ dengan tingkat signifikansi 0,007. Secara parsial citra merek dan kualitas produk berpengaruh positif atau signifikan terhadap kepuasan konsumen rotiboy di Kota Banda Aceh. Sedangkan promosi tidak berpengaruh positif atau signifikan terhadap kepuasan konsumen rotiboy di Kota Banda Aceh.

\section{DAFTAR PUSTAKA}

Ghozali, I. 2011. Aplikasi Analisis Multivariate Dengan Program IBM SPSS 19. Edisi Kelima. Universitas Diponegoro. Semarang

Pengaruh Citra Merek, Kualitas Produk dan Promosi Terhadap Kepuasan Konsumen Produk Rotiboy 236 di Kota Banda Aceh (Istiqarah Isa Putri, Rahmaddiansyah, Sofyan) 
Nasir. 2003. Metode Analisis Kuantitatif Regresi Linier Berganda. Gramedia. Jakarta

Setiadi, N. J. 2003. Perilaku Konsumen: Konsep dan Implikasi untuk Strategi dan Penelitian Pemasaran. Jakarta: Prenada Media.

Simamora, B.2004. Riset Pemasaran. Filsafa, Teori, dan Aplikasi. Gramedia Pustaka Utama. Jakarta

Sugiyono. 2004. Metode Penelitian Pendidikan. CV. Alfabeta. Bandung

Suliyanto, 2005. Analisis Data Dalam Aplikasi Pemasaran. Ghalia Indonesia. Bogor.

Wikipedia. Rotiboy. https//id.wikipedia.org/wiki/Rotiboy. Diakses tanggal 20 Januari 2016 